\title{
Association between Arsenic Exposure and Diabetes: A Meta-Analysis
}

\author{
Tzu-Ching Sung, ${ }^{1,2}$ Jhih-Wei Huang, ${ }^{3}$ and How-Ran Guo ${ }^{2,3,4}$ \\ ${ }^{1}$ Department of Health Care Management, University of Kang Ning, 188 Anjhong Road, Section 5, Tainan 70970, Taiwan \\ ${ }^{2}$ Center for Occupational and Environmental Health and Preventive Medicine, National Cheng Kung University, \\ 138 Sheng-Li Road, Tainan 70428, Taiwan \\ ${ }^{3}$ Department of Environmental and Occupational Health, College of Medicine, National Cheng Kung University, \\ 138 Sheng-Li Road, Tainan 70428, Taiwan \\ ${ }^{4}$ Department of Occupational and Environmental Medicine, National Cheng Kung University Hospital, \\ 138 Sheng-Li Road, Tainan 70428, Taiwan
}

Correspondence should be addressed to How-Ran Guo; hrguo@mail.ncku.edu.tw

Received 4 July 2014; Accepted 20 August 2014

Academic Editor: Shih-Bin Su

Copyright (C) 2015 Tzu-Ching Sung et al. This is an open access article distributed under the Creative Commons Attribution License, which permits unrestricted use, distribution, and reproduction in any medium, provided the original work is properly cited.

\begin{abstract}
Studies on the association between arsenic exposure and diabetes mellitus (DM) yielded inconsistent results. Epidemiologic data on the associations between arsenic exposures via inhalation and DM are limited. Therefore, we conducted a meta-analysis to evaluate the risk of DM associated with arsenic exposure. We searched the related literature through a systematic approach and analyzed the data according to the exposure route (inhalation and ingestion). We used random-effect models to estimate the summary relative risks (RRs) for DM associated with arsenic exposure and used $I^{2}$ statistics to assess the heterogeneity of studies. We identified 38 relevant studies, of which the 32 on the ingestion route showed a significant association between arsenic exposure and DM (RR $=$ 1.57; 95\% CI 1.27-1.93). Focusing on the 24 studies in which the diagnosis of DM was confirmed using laboratory tests or medical records, we found that the summary RR was 1.71 (95\% CI 1.32-2.23), very close to the overall estimates. We concluded that ingested arsenic is associated with the development of DM, but the heterogeneity among the studies may affect the results.
\end{abstract}

\section{Introduction}

Arsenic is widely distributed in nature environment and mainly transported through water. It can be found in inorganic and organic forms in the environment. Organic arsenic compounds are much less toxic than the inorganic forms, which are the predominant forms in surface and groundwater reservoirs. Arsenic can easily be released from soil into ground water, depending on the temperature, $\mathrm{pH}$, oxidation reduction potential, dissolved oxygen, and conductivity. For the general population, sources of arsenic exposures include air, drinking water, food, and industry (e.g., arsenic dust and fumes) [1].

Arsenic has been recognized as a human carcinogen for over a century [1], and studies have shown that arsenic exposure via air or drinking water may cause cancers of the lung [2, 3], bladder [4-6], skin [7], and kidney [1, 8]. In the past several decades, the associations between arsenic exposure and human cancers have been observed by many researchers in Taiwan $[1,9,10]$. In addition, arsenic exposure was found to be related to other diseases such as vascular [11] and heart diseases [10, 11]. Among them, some epidemiological studies found that arsenic exposure was associated with an increased risk of diabetes mellitus (DM), including those in Taiwan, Mexico, Bangladesh, Chile, Vietnam, Cambodia, Laos, and Thailand [12-15]. Most of the studies were in developing countries where groundwater was the primary source of drinking water, and the confounding effects caused by traditional risk factors such as diet, obesity, and living habits [16] were minimum. Nonetheless, studies on the associations between arsenic exposure and DM had inconsistent results $[14,17-22]$. In addition, although 


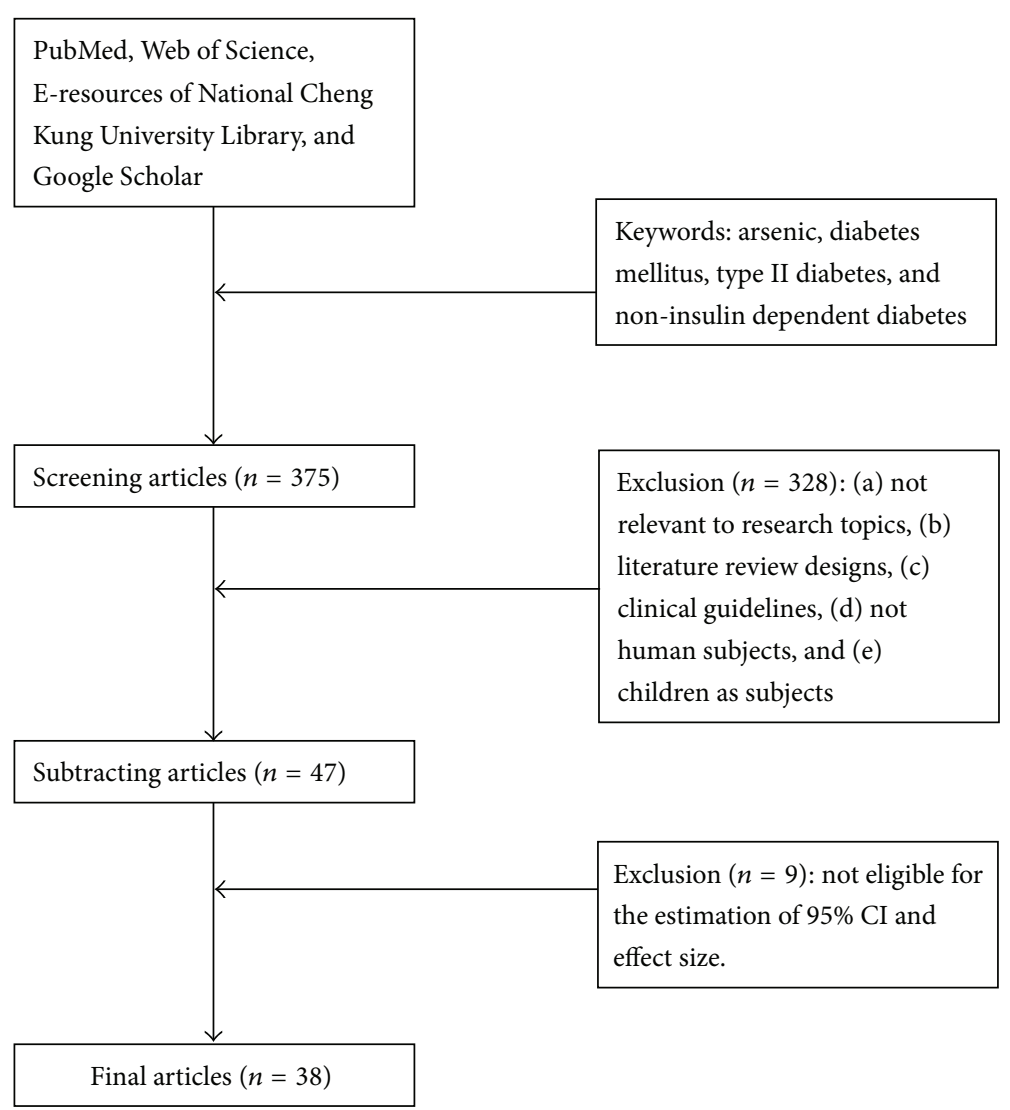

Figure 1: Protocol of references searching.

some meta-analyses have been conducted on the associations between inorganic arsenic in drinking water and DM [23, 24], they were mostly on exposures through ingestion, and those on the effects of arsenic exposures through inhalation were limited. Therefore, we conducted meta-analyses to evaluate the risks of DM associated with arsenic exposure through different exposure routes.

\section{Materials and Methods}

2.1. Definition of Diabetes Mellitus. Most studies adopted the fasting plasma glucose (FPG) method recommended by the American Diabetes Association (ADA) in 2003 for diagnosing DM [25]. ADA proposed that diabetes can be diagnosed with any one of the following three criteria: a FPG of $>126 \mathrm{mg} / \mathrm{dL}$ (after no caloric intake for at least eight hours), a casual plasma glucose $>200 \mathrm{mg} / \mathrm{dL}$ (taken at any time of day without regard to time of the last meal) with classic diabetes symptoms (increased urination, increased thirst, and unexplained weight loss), or an oral glucose tolerance test (OGTT) (75 g dose) of $>200 \mathrm{mg} / \mathrm{dL}$ for the two-hour sample. However, some studies were based on self-reported diagnosis.

2.2. Protocol of Literature Searching for Meta-Analyses. Metaanalysis is a quantitative review technique that may be used to aggregate the results and to explore and quantify the influence of potential moderating variables within a literature comprised of a variety of research items and methodologies $[26,27]$.

We conducted a literature search for epidemiological studies worldwide published between January 1, 1980, and January 1, 2014. Two researchers (JWH and TCS) independently searched literature by using academic databases including the PubMed, Web of Science, and Google Scholar. We followed the checklist for data reporting of the PRISMA Statement, $[28,29]$ except for the funding description of item 27. The eligibility criteria comprised (i) population exposed to arsenic, (ii) diabetes mellitus, (iii) outcome of DM related to arsenic described, and (iv) epidemiological studies. There were a total of 375 articles identified initially.

As recommended by Lipsey and Wilson (2001), the following articles were excluded: (a) not relevant to research topics, (b) literature review designs, (c) clinical guidelines, (d) not human subjects, and (e) children as subjects. Accordingly, 6 review articles (criterion b) and 322 articles (criteria a, c, d, and e) were excluded. In addition, we excluded 9 articles of which the estimates of $95 \%$ confidence intervals (CIs) and effect size were not available. As a result, 38 studies were included in our meta-analyses (Figure 1) [13-16, 18, 22, 30-61].

2.3. Statistical Analysis. We applied random-effect models (REMs) with the assumption that both within-study and between-study variations exist, which leads to wider and 
TABLE 1: Characteristics of studies.

\begin{tabular}{|c|c|c|c|c|}
\hline Study (reference) & Route & Case definition & Exposure indicator & Cases/population \\
\hline $\begin{array}{l}\text { Bartoli et al., } \\
1998[71]\end{array}$ & Ingestion & Death certificate & Living in exposure area & $3 / 488$ \\
\hline $\begin{array}{l}\text { Chen et al., } \\
2010[22]\end{array}$ & Ingestion & Self-report & Arsenic in drinking water & $241 / 11319$ \\
\hline $\begin{array}{l}\text { Coronado-González } \\
\text { et al., } 2007[13]^{*}\end{array}$ & Ingestion & $\begin{array}{c}\text { FPG } \\
\text { Medical records }\end{array}$ & Arsenic in urine & $200 / 400$ \\
\hline $\begin{array}{l}\text { del Razo et al., } \\
2011[18]^{*}\end{array}$ & Ingestion & FPG & Arsenic in drinking water & $25 / 258$ \\
\hline $\begin{array}{l}\text { Enterline and } \\
\text { Marsh, } 1982[72]\end{array}$ & Inhalation & Death certificate & Smelter workers versus general population & $12 / 1061$ \\
\hline $\begin{array}{l}\text { Ettinger et al., } \\
2009\left[^{4}\right]^{*}\end{array}$ & Ingestion & OGTT & Arsenic in blood & 456 \\
\hline $\begin{array}{l}\text { Huang et al., } \\
2014[16]^{*}\end{array}$ & Ingestion & $\begin{array}{c}\text { FPG } \\
\text { HbAlc }\end{array}$ & $\begin{array}{l}\text { Arsenic in drinking water } \\
\text { Arsenic in urine } \\
\text { Arsenic exposure skin signs }\end{array}$ & $14 / 142$ \\
\hline $\begin{array}{l}\text { Islam et al., } \\
2012 \text { [47] }^{*}\end{array}$ & Ingestion & $\begin{array}{c}\text { FPG } \\
\text { Self-report }\end{array}$ & Arsenic in drinking water & $47 / 1004$ \\
\hline $\begin{array}{l}\text { James et al., } \\
2013[40]^{*}\end{array}$ & Ingestion & $\begin{array}{c}\text { Medical records } \\
\text { Self-report }\end{array}$ & Arsenic in drinking water & $141 / 548$ \\
\hline $\begin{array}{l}\text { Jensen and Hansen, } \\
1998[73]^{*}\end{array}$ & Inhalation & $\mathrm{HbAlc}$ & Exposed versus unexposed workers & 64 \\
\hline $\begin{array}{l}\text { Jovanovic et al., } \\
2013[17]^{*}\end{array}$ & Ingestion & $\begin{array}{c}\text { National registry of } \\
\text { diabetes }\end{array}$ & Arsenic in drinking water & $242 / 195190$ \\
\hline $\begin{array}{l}\text { Kim and Lee, } \\
2011[19]^{*}\end{array}$ & Ingestion & $\begin{array}{c}\text { FPG } \\
\text { Self-report }\end{array}$ & $\begin{array}{l}\text { Arsenic in urine } \\
\text { Women } \\
\text { Men }\end{array}$ & $\begin{array}{l}79 / 891 \\
77 / 786\end{array}$ \\
\hline $\begin{array}{l}\text { Kim et al., } \\
2013 \text { [57] }^{*}\end{array}$ & Ingestion & Medical records & Arsenic in drinking water & $150 / 300$ \\
\hline $\begin{array}{l}\text { Lagerkvist and } \\
\text { Zetterlund, } 1994 \text { [32] }\end{array}$ & Inhalation & Self-report & Smelter workers versus unexposed reference & 89 \\
\hline $\begin{array}{l}\text { Lai et al., } \\
1994[14]^{*}\end{array}$ & Ingestion & $\begin{array}{l}\text { Medical history } \\
\text { OGTT } \\
\text { Self-report } \\
\end{array}$ & Arsenic in drinking water & $86 / 891$ \\
\hline $\begin{array}{l}\text { Lewis et al., } \\
1999 \text { [51] }\end{array}$ & Ingestion & Death certificate & $\begin{array}{c}\text { Arsenic in drinking water } \\
\text { Women } \\
\text { Men }\end{array}$ & $\begin{array}{l}35 / 961 \\
20 / 1242 \\
\end{array}$ \\
\hline $\begin{array}{l}\text { Lubin et al., } \\
2000[74]\end{array}$ & Inhalation & Death certificate & Smelter workers versus US general population & $54 / 5011$ \\
\hline $\begin{array}{l}\text { Mabuchi et al., } \\
1980[34]\end{array}$ & Inhalation & Death certificate & $\begin{array}{c}\text { Pesticide workers versus US general population } \\
\text { Men } \\
\text { Women }\end{array}$ & $\begin{array}{r}1 / 197 \\
1 / 43\end{array}$ \\
\hline $\begin{array}{l}\text { Makris et al., } \\
2012[21]\end{array}$ & Ingestion & Self-report & Arsenic in drinking water & 317 \\
\hline $\begin{array}{l}\text { Meliker et al., } 2007 \\
{[60]}\end{array}$ & Ingestion & Death certificate & $\begin{array}{c}\text { Arsenic in drinking water } \\
\text { Women } \\
\text { Men }\end{array}$ & $\begin{array}{c}1612 / 38722 \\
1249 / 41282 \\
\end{array}$ \\
\hline $\begin{array}{l}\text { Nabi et al., } \\
2005[75]^{*}\end{array}$ & Ingestion & Serum glucose & Arsenic in drinking water & $24 / 235$ \\
\hline $\begin{array}{l}\text { Navas-Acien et al., } \\
2008[50]^{*}\end{array}$ & Ingestion & $\begin{array}{c}\text { FPG } \\
\text { Self-report }\end{array}$ & Arsenic in urine & $93 / 788$ \\
\hline $\begin{array}{l}\text { Navas-Acien et al., } \\
2009[48]^{*}\end{array}$ & Ingestion & $\begin{array}{c}\text { FPG } \\
\text { Self-report } \\
\end{array}$ & Arsenic in urine & $62 / 1279$ \\
\hline $\begin{array}{l}\text { Rahman and } \\
\text { Axelson, } 1995 \text { [37] }\end{array}$ & Ingestion & Death certificate & Smelter workers versus unexposed & $43 / 369$ \\
\hline
\end{tabular}


TABle 1: Continued.

\begin{tabular}{|c|c|c|c|c|}
\hline Study (reference) & Route & Case definition & Exposure indicator & Cases/population \\
\hline $\begin{array}{l}\text { Mahfuzar Rahman } \\
\text { et al., } 1996 \text { [38] }\end{array}$ & Inhalation & Death certificate & $\begin{array}{c}\text { Glassworkers versus unexposed } \\
\text { Glassblowers } \\
\text { Unspecified glassworkers }\end{array}$ & $\begin{array}{c}6 / 74 \\
25 / 135 \\
\end{array}$ \\
\hline $\begin{array}{l}\text { Rahman et al., } \\
1998 \text { [15] }^{*}\end{array}$ & Ingestion & $\begin{array}{c}\text { OGTT } \\
\text { Glucosuria } \\
\text { Self-report }\end{array}$ & Arsenic exposure skin signs & $18 / 1107$ \\
\hline $\begin{array}{l}\text { Rahman et al., } \\
1999 \text { [76] }^{*}\end{array}$ & Ingestion & Glucosuria & Arsenic in drinking water & $105 / 1481$ \\
\hline $\begin{array}{l}\text { Rhee et al., } \\
2013 \text { [39] }^{*}\end{array}$ & Ingestion & $\begin{array}{c}\text { FPG } \\
\text { Serum insulin }\end{array}$ & Arsenic in urine & $309 / 3602$ \\
\hline $\begin{array}{l}\text { Ruiz-Navarro et al., } \\
1998 \text { [52] }^{*}\end{array}$ & Ingestion & Medical records & Arsenic in urine & $38 / 126$ \\
\hline $\begin{array}{l}\text { Steinmaus et al., } \\
2009\left[^{*} 77\right]^{*}\end{array}$ & Ingestion & $\begin{array}{c}\text { FPG } \\
\text { Self-report } \\
\end{array}$ & Arsenic in urine & 795 \\
\hline $\begin{array}{l}\text { Tollestrup et al., } \\
2003 \text { [78] }\end{array}$ & Ingestion & Death certificate & $\begin{array}{c}\text { Living in exposure area } \\
\text { Men } \\
\text { Women }\end{array}$ & $\begin{array}{r}3 / 162 \\
1 / 110 \\
\end{array}$ \\
\hline $\begin{array}{l}\text { Tsai et al., } \\
1999 \text { [56] }\end{array}$ & Ingestion & Death certificate & $\begin{array}{c}\text { Arsenic in drinking water } \\
\text { Men } \\
\text { Women } \\
\end{array}$ & $\begin{array}{c}188 / 11193 \\
343 / 8874\end{array}$ \\
\hline $\begin{array}{l}\text { Tseng et al., } \\
2000[44]^{*}\end{array}$ & Ingestion & $\begin{array}{c}\text { FPG } \\
\text { OGTT }\end{array}$ & Arsenic in drinking water & $41 / 446$ \\
\hline $\begin{array}{l}\text { Wang et al., } \\
2003 \text { [59 }^{*}\end{array}$ & Ingestion & Medical records & Arsenic in drinking water & $5998 / 706314$ \\
\hline $\begin{array}{l}\text { Wang et al., } \\
2007[53]^{*}\end{array}$ & Ingestion & FPG & Arsenic in hair & $166 / 660$ \\
\hline $\begin{array}{l}\text { Wang et al., } \\
2009[45]^{*}\end{array}$ & Ingestion & Medical records & Arsenic in drinking water & 235 \\
\hline $\begin{array}{l}\text { Ward and Pim, } \\
1984[79]^{*}\end{array}$ & Ingestion & Medical records & Arsenic in plasma & 117 \\
\hline $\begin{array}{l}\text { Zierold et al., } \\
2004 \text { [46] }\end{array}$ & Ingestion & Self-report & Arsenic in drinking water & 1185 \\
\hline
\end{tabular}

FPG: fasting plasma glucose; OGTT: oral glucose tolerance test; ${ }^{*}$ the diagnosis of DM is confirmed by laboratory tests or medical records.

more conservative CIs than fixed effect models (which assume that there is only within-study variation in the mean outcomes of a study and that interstudy variations can be excluded) [62]. Pooled measures were calculated to assess the associations between arsenic exposure and DM, and we conducted separate analyses of studies using arsenic in the drinking water and arsenic in the air for exposure assessment.

Recognizing the fact that the validity of self-reported diagnosis of DM is sometimes questionable, in addition to the analyses that included all relevant studies, we also performed a separate analysis on studies in which the diagnosis of DM was confirmed using laboratory tests, mostly FPG or the oral glucose tolerance test (OGTT), or medical records.

The study-specific adjusted relative risks (RRs) were used as the measure of association across studies. On the basis of the assumption that estimates of odd ratios (ORs) from casecontrol studies and risk, rate, and hazard ratios from cohort studies were all valid estimates of the RR, we therefore report all results as the RR for simplicity. For those studies that did not use the lowest exposure level as the reference for comparison, we recalculated RRs using the effective count method deriving relative effect and precision estimates for alternative comparisons from a set of estimates presented by exposure level or disease category [63]. To assess the heterogeneity among studies in the metaregression analyses, we calculated the $I^{2}$ statistic [64]. The $I^{2}$ statistic can be interpreted roughly as $0 \%$ to $40 \%$ indicating that the level of heterogeneity is not remarkable, $30 \%$ to $60 \%$ indicating moderate heterogeneity, $50 \%$ to $90 \%$ indicating substantial heterogeneity, and $75 \%$ to $100 \%$ indicating considerable heterogeneity. All statistical tests were performed at a two-sided significant level of 0.05 , and all statistical analyses were carried out using the Comprehensive Meta-Analysis V2 software.

\section{Results}

There were 38 published studies eligible for meta-analysis on the association between arsenic exposure and DM. We 


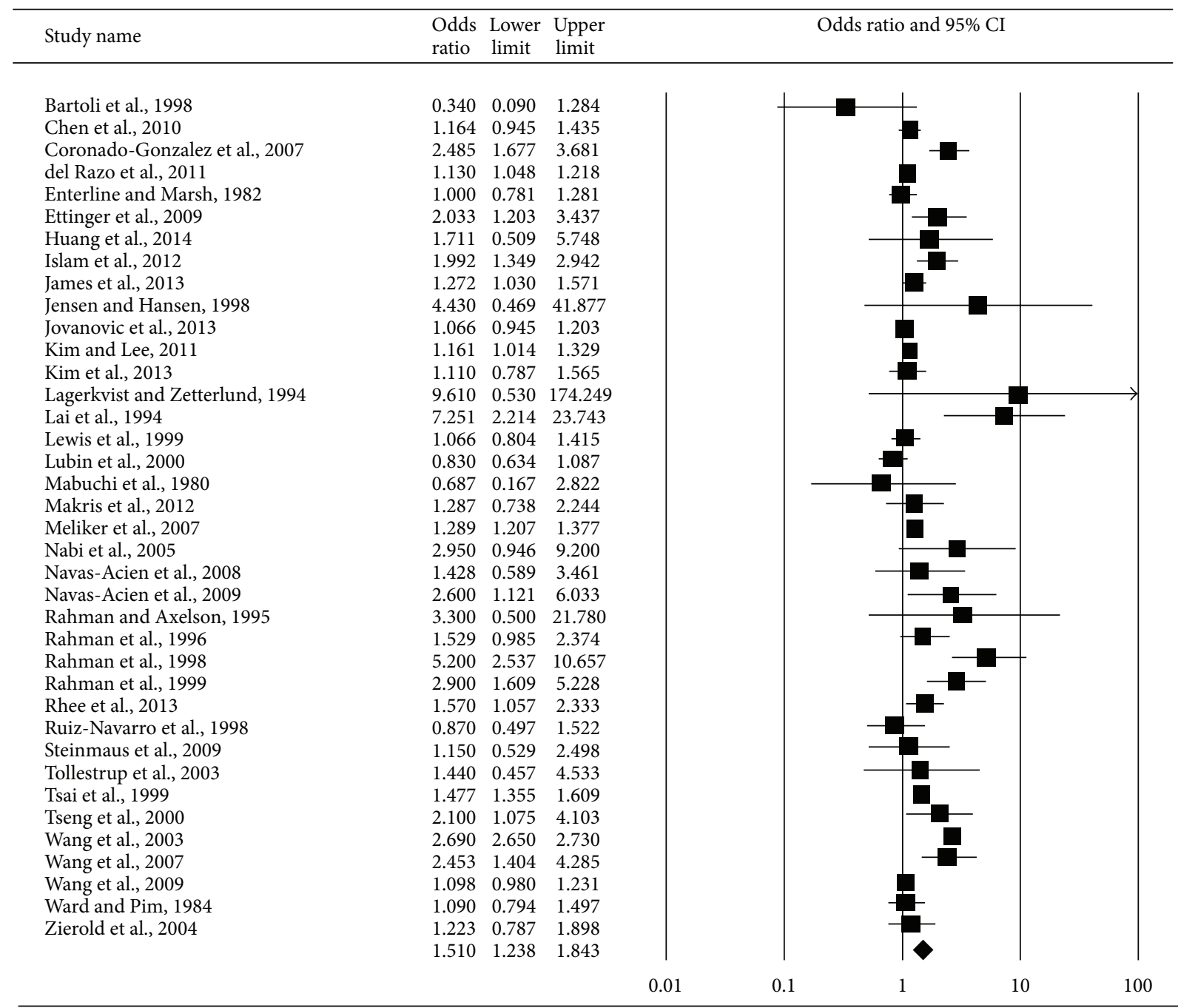

FIGURE 2: Synthesis forest plot for a random-effect meta-analysis of studies on arsenic exposure and DM. The size of the box is proportional to the weight assigned to each study, which is inversely proportional to the relative risk, and the horizontal line represents the $95 \%$ confidence interval.

summarized the main characteristics, including route of exposure, case definition, case number, population size, and relative risk with associated 95\% CI of each study in Table 1. Most studies were published after 1990, and the earlier studies were mostly on inhalation exposures, 2 out of 3 before 1990, and the latest was back in 2000. The early studies reporting associations between arsenic via drinking water and DM were published in Bangladesh and Taiwan. A relatively large proportion of papers were published after 2010, 10 out of 38 from 2010 to 2014. More than half ( $n=$ 21 ) of the 38 studies used the cross-sectional study design, and the rest included 9 cohort studies and 7 case-control studies.

Of the 38 studies we included in this study, 7 used arsenic in the urine as an indicator of exposure, 18 used arsenic in the drinking water, and 2 used skin symptoms of arsenicosis. Two studies used arsenic in both urine and drinking water as exposure indicators, including one using all three indicators. The summary RR for DM associated with arsenic exposures of these 38 studies was 1.52 (95\% CI 1.24-1.85). There was considerable heterogeneity among these studies $\left(I^{2}=98.17 \%\right.$; $P<0.001$ ) (Figure 2).

The primary routes of arsenic exposure are ingestion and inhalation, with ingestion as the predominant route (32 out of 38). We conducted a subgroup analysis for these 38 studies stratified into two categories according to the route of exposure: by inhalation and by ingestion. There were six studies [30-35] in the inhalation-route category, and all of them were occupational cohorts: copper smelter workers, wood workers, and pesticide workers. None of the studies had data on exposure level, and the RRs were compared between exposed workers and reference populations, either a group of unexposed workers or the general population. The summary risk did not reach statistical significance $(\mathrm{RR}=1.08 ; 95 \% \mathrm{CI}$ 0.79-1.46) (Figure 3), and there was moderate heterogeneity among the studies $\left(I^{2}=48.51 \% ; P=0.084\right)$.

The other 32 studies were included in the ingestion-route category. While some of them simply compared the risks 


\begin{tabular}{lcccc}
\hline Study name & $\begin{array}{c}\text { Odds } \\
\text { ratio }\end{array}$ & $\begin{array}{c}\text { Lower } \\
\text { limit }\end{array}$ & $\begin{array}{c}\text { Upper } \\
\text { limit }\end{array}$ \\
\hline Enterline and Marsh, 1982 & 1.000 & 0.781 & 1.281 & Odds ratio and 95\% CI \\
Jensen and Hansen, 1998 & 4.430 & 0.469 & 41.877 \\
Lagerkvist and Zetterlund, 1994 & 9.610 & 0.530 & 174.249 \\
Lubin et al., 2000 & 0.830 & 0.634 & 1.087 \\
Mabuchi et al., 1980 & 0.687 & 0.167 & 2.822 \\
Rahman et al., 1996 & 1.529 & 0.985 & 2.374 \\
& 1.076 & 0.790 & 1.464 &
\end{tabular}

FIGURE 3: Synthesis forest plot for a random-effect meta-analysis of studies on arsenic exposure through inhalation and DM. The size of the box is proportional to the weight assigned to each study, which is inversely proportional to the relative risk, and the horizontal line represents the $95 \%$ confidence interval.

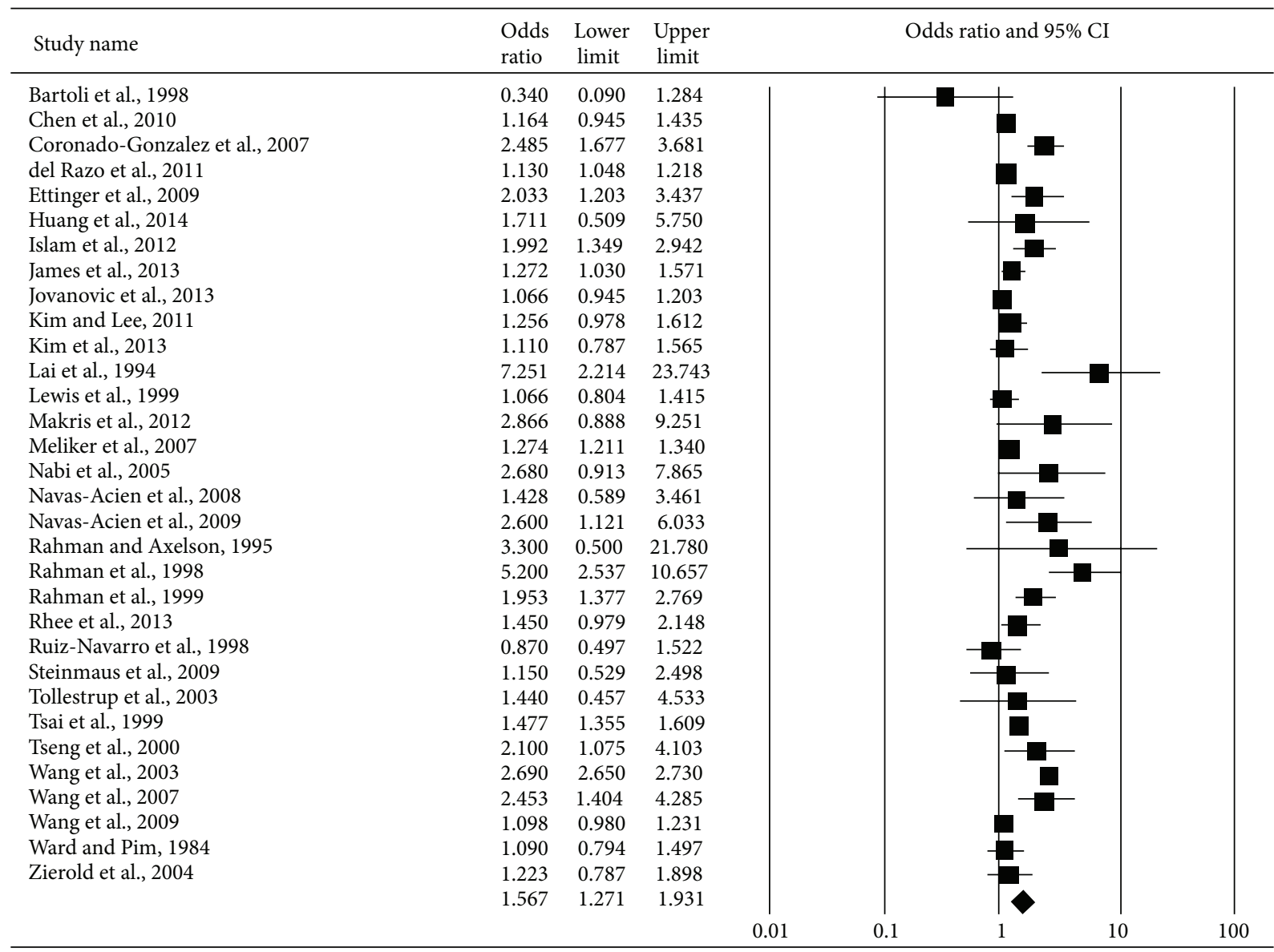

FIGURE 4: Synthesis forest plot for a random-effect meta-analysis of studies on arsenic exposure through ingestion and DM. The size of the box is proportional to the weight assigned to each study, which is inversely proportional to the relative risk, and the horizontal line represents the $95 \%$ confidence interval.

between exposed and unexposed populations, as in the studies on exposures through inhalation, most (28 out of 32) had certain measurements of the exposure levels. Of these studies, the summary RR was 1.57 (95\% CI 1.27-1.93) (Figure 4). Likewise, considerable heterogeneity was noted $\left(I^{2}=98.38 \% ; P<0.001\right)$.

In 24 studies, the diagnosis of DM was confirmed using laboratory tests or medical records. When we excluded the studies without confirmed diagnoses, the estimated pooled RR was 1.71 (95\% CI 1.32-2.23) (Figure 5), similar to that from the overall analysis of studies on arsenic exposures through ingestion. This suggested that the reporting of DM in studies without confirmed diagnoses was accurate in most cases or at least indicated that the misclassifications in the DM status in studies without confirmed diagnoses were nearly random in terms of (independent of) arsenic exposure. However, as in 


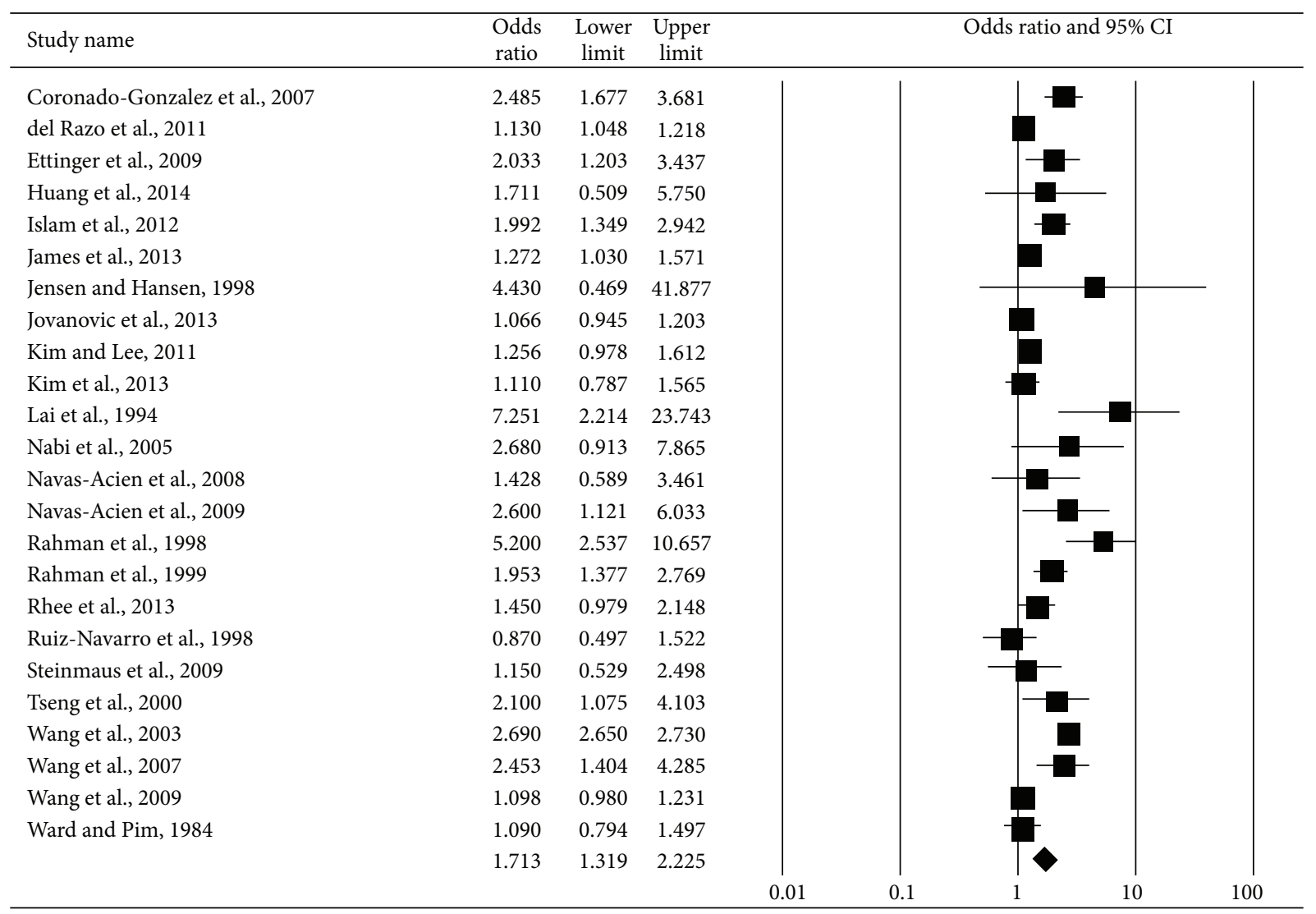

Figure 5: Synthesis forest plot for a random-effect meta-analysis of studies on arsenic exposure through ingestion and DM, in which the diagnosis of DM was confirmed using laboratory tests or medical records. The size of the box is proportional to the weight assigned to each study, which is inversely proportional to the relative risk, and the horizontal line represents the $95 \%$ confidence interval.

the overall analysis of studies on arsenic exposures through ingestion, considerable heterogeneity was still noted $\left(I^{2}=\right.$ 97.85\%; $P<0.001)$.

\section{Discussions}

Our results support an association between ingested arsenic exposure and DM in humans. No significant associations were observed between arsenic exposure through inhalation and the risk of developing DM. Most studies used the arsenic level in drinking water as an indicator of exposure to assess the association [17, 21, 36, 38, 42, 48,65-67], and only a recent study used skin changes of arsenicosis as an indicator of exposure to arsenic [16].

The possible mechanisms of inorganic arsenic inducing type $2 \mathrm{DM}$ through interfering with insulin-stimulated signal transduction pathway or with critical steps in glucose metabolism have been investigated by Walton et al. [68]. They recognized that all trivalent arsenicals suppressed expression and possibly phosphorylation of protein kinase $\mathrm{B}$ (PKB/Akt). Arsenic trioxide was also found to induce the expression and the phosphorylation of $\mathrm{PKB} / \mathrm{Akt}$ and inhibit the interaction between PKB/Akt and PPARgamma [69]. PKB/Akt suppresses apoptosis and negatively regulates preadipocyte differentiation. Furthermore, arsenic induced inhibition of adipogenesis may occur in the early stage of terminal adipogenic differentiation which indicated a correlation with C/EBP homologous protein (CHOP10), an endoplasmic reticulum stress response protein [70].

Many studies had a relatively small sample size and might suffer from limited study power, but our meta-analyses obtained a larger statistical power by aggregating studies. To increase the accuracy of the diagnosis of DM, we conducted a separate analysis of studies using laboratory tests or medical records for confirming the diagnosis [25] and found that the summary RR remained about the same.

Due to various reasons such as the fact that studies with small samples sizes or no findings with statistical significance are less likely to be published, meta-analyses may be affected by publication bias. We assessed such bias with visual inspection of the funnel plot, Egger's regression asymmetry test, and Begg's Rank Correlation method by examining the relationship between the standardized treatment effect and the variance of the treatment effect using Kendall's Tau. The results showed indications of publication bias and suggested that caution should be taken when interpreting the results.

The heterogeneities among studies we observed in our analyses might be contributable to a number of characteristics that varied among the studies such as age, gender, 
study design, design quality, arsenic exposure levels, and covariates. There were distinct differences in the reported effects (statistical heterogeneity), study design (methodological heterogeneity), and characteristics of the participants and outcome measures (clinical heterogeneity). Nonetheless, results of our analyses are consistent with the findings from a previous meta-analysis [24] which showed an increased DM risk associated with arsenic exposure.

Because most previous studies were retrospective or cross-sectional studies, further research efforts should be placed on prospective studies, especially those with better controls of potential confounders. In addition, dose-response assessments should be performed, so that regulation of arsenic levels in drinking water can have a more solid scientific basis. Furthermore, with the existing evidence, we believe that interventional studies should be conducted not only for confirming arsenic as a causal agent of DM but also for preventing DM in the endemic areas of exposure.

\section{Conflict of Interests}

The authors declare that there is no conflict of interests regarding the publication of this paper.

\section{Authors' Contribution}

Tzu-Ching Sung and Jhih-Wei Huang contributed equally to the work.

\section{Acknowledgment}

This study was supported in part by Grant no. NSC-98-2911I-006-034 from the National Science Council of Taiwan.

\section{References}

[1] C.-J. Chen, C. W. Chen, M.-M. Wu, and T.-L. Kuo, "Cancer potential in liver, lung, bladder and kidney due to ingested inorganic arsenic in drinking water," British Journal of Cancer, vol. 66, no. 5, pp. 888-892, 1992.

[2] H.-R. Guo, "Arsenic level in drinking water and mortality of lung cancer (Taiwan)," Cancer Causes and Control, vol. 15, no. 2, pp. 171-177, 2004.

[3] S. McSheehy, J. Szpunar, R. Lobinski, V. Haldys, J. Tortajada, and J. S. Edmonds, "Characterization of arsenic species in kidney of the clam Tridacna derasa by multidimensional liquid chromatography-ICPMS and electrospray time-of-flight tandem mass spectrometry," Analytical Chemistry, vol. 74, no. 10, pp. 2370-2378, 2002.

[4] C.-H. Chen, H.-Y. Chiou, Y.-M. Hsueh, C.-J. Chen, H.-J. Yu, and Y.-S. Pu, "Clinicopathological characteristics and survival outcome of arsenic related bladder cancer in Taiwan," Journal of Urology, vol. 181, no. 2, pp. 547-553, 2009.

[5] H.-R. Guo, "Age adjustment in ecological studies: using a study on arsenic ingestion and bladder cancer as an example," $B M C$ Public Health, vol. 11, article 820, 2011.

[6] H.-R. Guo and Y.-C. Tseng, "Arsenic in drinking water and bladder cancer: comparison between studies based on cancer registry and death certificates," Environmental Geochemistry and Health, vol. 22, no. 2, pp. 83-91, 2000.
[7] H.-R. Guo, S. R. Lipsitz, H. Hu, and R. R. Monson, "Using ecological data to estimate a regression model for individual data: the association between arsenic in drinking water and incidence of skin cancer," Environmental Research, vol. 79, no. 2, pp. 82-93, 1998.

[8] C. Hopenhayn-Rich, M. L. Biggs, and A. H. Smith, "Lung and kidney cancer mortality associated with arsenic in drinking water in Cordoba, Argentina," International Journal of Epidemiology, vol. 27, no. 4, pp. 561-569, 1998.

[9] C.-J. Chen and C.-J. Wang, "Ecological correlation between arsenic level in well water and age-adjusted mortality from malignant neoplasms," Cancer Research, vol. 50, no. 17, pp. 5470-5474, 1990.

[10] C.-J. Chen, "Blackfoot disease," The Lancet, vol. 336, no. 8712, p. 442, 1990.

[11] M.-M. Wu, T.-L. Kuo, Y.-H. Hwang, and C.-J. Chen, "Doseresponse relation between arsenic concentration in well water and mortality from cancers and vascular diseases," The American Journal of Epidemiology, vol. 130, no. 6, pp. 1123-1132, 1989.

[12] K. H. Cho, S. Sthiannopkao, Y. A. Pachepsky, K.-W. Kim, and J. H. Kim, "Prediction of contamination potential of groundwater arsenic in Cambodia, Laos, and Thailand using artificial neural network," Water Research, vol. 45, no. 17, pp. 5535-5544, 2011.

[13] J. A. Coronado-González, L. M. Del Razo, G. García-Vargas, F. Sanmiguel-Salazar, and J. Escobedo-de la Peña, "Inorganic arsenic exposure and type 2 diabetes mellitus in Mexico," Environmental Research, vol. 104, no. 3, pp. 383-389, 2007.

[14] M.-S. Lai, Y.-M. Hsueh, C.-J. Chen et al., "Ingested inorganic arsenic and prevalence of diabetes mellitus," The American Journal of Epidemiology, vol. 139, no. 5, pp. 484-492, 1994.

[15] M. Rahman, M. Tondel, S. A. Ahmad, and O. Axelson, "Diabetes mellitus associated with arsenic exposure in Bangladesh," The American Journal of Epidemiology, vol. 148, no. 2, pp. 198-203, 1998.

[16] J. W. Huang, Y. Y. Cheng, T. C. Sung, H. R. Guo, and S. Sthiannopkao, "Association between arsenic exposure and diabetes mellitus in Cambodia," BioMed Research International, vol. 2014, Article ID 683124, 7 pages, 2014.

[17] D. Jovanovic, Z. Rasic-Milutinovic, K. Paunovic, B. Jakovljevic, S. Plavsic, and J. Milosevic, "Low levels of arsenic in drinking water and type 2 diabetes in Middle Banat region, Serbia," International Journal of Hygiene and Environmental Health, vol. 216, no. 1, pp. 50-55, 2013.

[18] L. M. del Razo, G. G. García-Vargas, O. L. Valenzuela et al., "Exposure to arsenic in drinking water is associated with increased prevalence of diabetes: a cross-sectional study in the Zimapán and Lagunera regions in Mexico," Environmental Health: A Global Access Science Source, vol. 10, no. 1, article 73, 2011.

[19] Y. Kim and B.-K. Lee, "Association between urinary arsenic and diabetes mellitus in the Korean general population according to KNHANES 2008," Science of the Total Environment, vol. 409, no. 19, pp. 4054-4062, 2011.

[20] X. Li, B. Li, S. Xi, Q. Zheng, X. Lv, and G. Sun, "Prolonged environmental exposure of arsenic through drinking water on the risk of hypertension and type 2 diabetes," Environmental Science and Pollution Research, vol. 20, no. 11, pp. 8151-8161, 2013.

[21] K. C. Makris, C. A. Christophi, M. Paisi, and A. S. Ettinger, "A preliminary assessment of low level arsenic exposure and diabetes mellitus in Cyprus," BMC Public Health, vol. 12, no. 1, article 334, 2012. 
[22] Y. Chen, H. Ahsan, V. Slavkovich et al., "No association between arsenic exposure from drinking water and diabetes mellitus: a cross-sectional study in Bangladesh," Environmental Health Perspectives, vol. 118, no. 9, pp. 1299-1305, 2010.

[23] A. Becker and D. Axelrad, "Arsenic and type 2 diabetes: commentary on association of inorganic arsenic exposure with type 2 diabetes mellitus: a meta-analysis by Wang et al," Journal of Epidemiology and Community Health, vol. 68, no. 5, pp. 393395, 2014.

[24] W. Wang, Z. Xie, Y. Lin, and D. Zhang, "Association of inorganic arsenic exposure with type 2 diabetes mellitus: a meta-analysis," Journal of Epidemiology and Community Health, vol. 68, no. 2, pp. 176-184, 2014.

[25] S. Genuth, K. G. M. M. Alberti, P. Bennett et al., "Follow-up report on the diagnosis of diabetes mellitus," Diabetes Care, vol. 26, no. 11, pp. 3160-3167, 2003.

[26] M. W. Lipsey and D. B. Wilson, Practical Meta-Analysis, Sage, London, UK, 2001.

[27] M. Borenstein, L. V. Hedges, J. P. T. Higgins, and H. R. Rothstein, Introduction to Meta-Analysis, Wiley, Chichester, UK, 2009.

[28] D. Moher, A. Liberati, J. Tetzlaff, and D. G. Altman, "Preferred reporting items for systematic reviews and meta-analyses: the PRISMA statement," PLoS Medicine, vol. 6, Article ID e1000097, 2009.

[29] A. Liberati, D. G. Altman, J. Tetzlaff et al., "The PRISMA statement for reporting systematic reviews and meta-analyses of studies that evaluate health care interventions: explanation and elaboration," PLoS Medicine, vol. 6, no. 7, Article ID e1000100, 2009.

[30] P. E. Enterline and G. M. Marsh, "Mortality studies of smelter workers," American Journal of Industrial Medicine, vol. 1, no. 34, pp. 251-259, 1980.

[31] I. H. Lubin, L. M. Pottern, W. J. Blot, S. Tokudome, B. J. Stone, and J. F. Fraumeni Jr., "Respiratory cancer among copper smelter workers: recent mortality statistics," Journal of Occupational Medicine, vol. 23, no. 11, pp. 779-784, 1981.

[32] B. J. Lagerkvist and B. Zetterlund, "Assessment of exposure to arsenic among smelter workers: a five-year follow-up," American Journal of Industrial Medicine, vol. 25, no. 4, pp. 477488, 1994.

[33] G. E. Jensen and I. L. B. Olsen, "Occupational exposure to inorganic arsenic in wood workers and taxidermists-air sampling and biological monitoring," Journal of Environmental Science and Health A: Environmental Science and Engineering, vol. 30, no. 4, pp. 921-938, 1995.

[34] K. Mabuchi, A. M. Lilienfeld, and L. M. Snell, "Cancer and occupational exposure to arsenic: a study of pesticide workers," Preventive Medicine, vol. 9, no. 1, pp. 51-77, 1980.

[35] O. Axelson, E. Dahlgren, C. D. Jansson, and S. O. Rehnlund, "Arsenic exposure and mortality: a case-referent study from a Swedish copper smelter," British Journal of Industrial Medicine, vol. 35 , no. 1 , pp. 8-15, 1978 .

[36] A. Navas-Acien and E. Guallar, "Arsenic exposure and diabetes mellitus in the United States-reply," Journal of the American Medical Association, vol. 300, no. 23, pp. 2728-2729, 2008.

[37] M. Rahman and O. Axelson, "Diabetes mellitus and arsenic exposure: a second look at case-control data from a Swedish copper smelter," Occupational and Environmental Medicine, vol. 52, no. 11, pp. 773-774, 1995.

[38] M. D. Mahfuzar Rahman, G. Wingren, and O. Axelson, "Diabetes mellitus among Swedish art glass workers-an effect of arsenic exposure?" Scandinavian Journal of Work, Environment and Health, vol. 22, no. 2, pp. 146-149, 1996.

[39] S. Y. Rhee, Y.-C. Hwang, J.-T. Woo, S. O. Chin, S. Chon, and Y. S. Kim, "Arsenic exposure and prevalence of diabetes mellitus in Korean adults," Journal of Korean Medical Science, vol. 28, no. 6, pp. 861-868, 2013.

[40] K. A. James, J. A. Marshall, J. E. Hokanson, J. R. Meliker, G. O. Zerbe, and T. E. Byers, "A case-cohort study examining lifetime exposure to inorganic arsenic in drinking water and diabetes mellitus," Environmental Research, vol. 123, pp. 33-38, 2013.

[41] S. H. Lamm, A. Engel, and M. Feinleib, "Arsenic exposure and diabetes mellitus risk," Journal of Occupational and Environmental Medicine, vol. 48, no. 10, pp. 1001-1003, 2006.

[42] A. S. Ettinger, A. R. Zota, C. J. Amarasiriwardene et al., "Maternal arsenic exposure and impaired glucose tolerance during pregnancy," Environmental Health Perspectives, vol. 117, no. 7, pp. 1059-1064, 2009.

[43] C.-H. Tseng, "Arsenic exposure and diabetes mellitus in the United States," The Journal of the American Medical Association, vol. 300 , no. 23, p. $2728,2008$.

[44] C.-H. Tseng, T.-Y. Tai, C.-K. Chong et al., "Long-term arsenic exporure and incidence of non-insulin-dependent diabetes mellitus: a cohort study in arseniasis-hyperendemic villages in Taiwan," Environmental Health Perspectives, vol. 108, no. 9, pp. 847-851, 2000.

[45] J. P. Wang, S. L. Wang, Q. Lin, L. Zhang, D. Huang, and J. C. $\mathrm{Ng}$, "Association of arsenic and kidney dysfunction in people with diabetes and validation of its effects in rats," Environment International, vol. 35, no. 3, pp. 507-511, 2009.

[46] K. M. Zierold, L. Knobeloch, and H. Anderson, "Prevalence of chronic diseases in adults exposed to arsenic-contaminated drinking water," American Journal of Public Health, vol. 94, no. 11, pp. 1936-1937, 2004.

[47] M. R. Islam, I. Khan, S. M. N. Hassan et al., "Association between type 2 diabetes and chronic arsenic exposure in drinking water: a cross sectional study in Bangladesh," Environmental Health: A Global Access Science Source, vol. 11, no. 1, article no. 38, 2012.

[48] A. Navas-Acien, E. K. Silbergeld, R. Pastor-Barriuso, and E. Guallar, "Rejoinder: arsenic exposure and prevalence of type 2 diabetes updated findings from the national health nutrition and examination survey, 2003-2006," Epidemiology, vol. 20, no. 6, pp. 816-820, 2009.

[49] A. Navas-Acien, "Exploring links between arsenic and diabetes, with Ana Navas-Acien. Interview by Ashley Ahearn," Environmental Health Perspectives, vol. 120, no. 11, 2012.

[50] A. Navas-Acien, E. K. Silbergeld, R. Pastor-Barriuso, and E. Guallar, "Arsenic exposure and prevalence of type 2 diabetes in US adults," Journal of the American Medical Association, vol. 300, no. 7, pp. 814-822, 2008.

[51] D. R. Lewis, J. W. Southwick, R. Ouellet-Hellstrom, J. Rench, and R. L. Calderon, "Drinking water arsenic in Utah: a cohort mortality study," Environmental Health Perspectives, vol. 107, no. 5, pp. 359-365, 1999.

[52] M. L. Ruiz-Navarro, M. Navarro-Alarcón, H. Lopez Ga-De La Serrana, V. Pérez-Valero, and M. C. López-Martinez, "Urine arsenic concentrations in healthy adults as indicators of environmental contamination: relation with some pathologies," Science of the Total Environment, vol. 216, no. 1-2, pp. 55-61, 1998.

[53] S.-L. Wang, F.-H. Chang, S.-H. Liou, H.-J. Wang, W.-F. Li, and D. P. H. Hsieh, "Inorganic arsenic exposure and its relation to 
metabolic syndrome in an industrial area of Taiwan," Environment International, vol. 33, no. 6, pp. 805-811, 2007.

[54] J.-M. Chiou, S.-L. Wang, C.-J. Chen, C.-R. Deng, W. Lin, and T.Y. Tai, "Arsenic ingestion and increased microvascular disease risk: observations from the south-western arseniasis-endemic area in Taiwan," International Journal of Epidemiology, vol. 34, no. 4, pp. 936-943, 2005.

[55] B. K. Lee and Y. Kim, "Association of diabetes mellitus with a combination of vitamin d deficiency and arsenic exposure in the korean general population: analysis of 2008-2009 Korean national health and nutrition examination survey data," Annals of Occupational and Environmental Medicine, vol. 25, article 7, 2013.

[56] S.-M. Tsai, T.-N. Wang, and Y.-C. Ko, "Mortality for certain diseases in areas with high levels of arsenic in drinking water," Archives of Environmental Health, vol. 54, no. 3, pp. 186-193, 1999.

[57] N. H. Kim, C. C. Mason, R. G. Nelson et al., "Arsenic exposure and incidence of type 2 diabetes in southwestern American Indians," The American Journal of Epidemiology, vol. 177, no. 9, pp. 962-969, 2013.

[58] P. Apostoli, M. Sarnico, P. Bavazzano, and D. Bartoli, "Arsenic and porphyrins," American Journal of Industrial Medicine, vol. 42, no. 3, pp. 180-187, 2002.

[59] S.-L. Wang, J.-M. Chiou, C.-J. Chen et al., "Prevalence of non-insulin-dependent diabetes mellitus and related vascular diseases in southwestern arseniasis-endemic and nonendemic areas in Taiwan," Environmental Health Perspectives, vol. 111, no. 2, pp. 155-159, 2003.

[60] J. R. Meliker, R. L. Wahl, L. L. Cameron, and J. O. Nriagu, "Arsenic in drinking water and cerebrovascular disease, diabetes mellitus, and kidney disease in Michigan: a standardized mortality ratio analysis," Environmental Health: A Global Access Science Source, vol. 6, article 4, 2007.

[61] F. J. Frost, T. Muller, H. V. Petersen, B. Thomson, and K. Tollestrup, "Identifying US populations for the study of health effects related to drinking water arsenic," Journal of Exposure Analysis and Environmental Epidemiology, vol. 13, no. 3, pp. 231239, 2003.

[62] H. A. Chu and D. J. Crawford-Brown, "Inorganic arsenic in drinking water and bladder cancer: a meta-analysis for doseresponse assessment," International Journal of Environmental Research and Public Health, vol. 3, no. 4, pp. 316-322, 2006.

[63] J. Hamling, P. Lee, R. Weitkunat, and M. Ambuhl, "Facilitating meta-analyses by deriving relative effect and precision estimates for alternative comparisons from a set of estimates presented by exposure level or disease category," Statistics in Medicine, vol. 27, no. 7, pp. 954-970, 2008.

[64] J. P. T. Higgins and S. G. Thompson, "Quantifying heterogeneity in a meta-analysis," Statistics in Medicine, vol. 21, no. 11, pp. 15391558, 2002.

[65] M. R. Islam, I. Khan, S. M. N. Hassan et al., "Association between type 2 diabetes and chronic arsenic exposure in drinking water: a cross sectional study in Bangladesh," Environmental Health, vol. 11, no. 1, article no. 38, 2012.

[66] I. Khan, S. Hassan, M. McEvoy et al., "Association between type 2 diabetes and chronic arsenic exposure in Bangladesh," Epidemiology, vol. 22, p. S154, 2011.

[67] M. S. Lai, Y. M. Hsueh, C. J. Chen et al., "Ingested inorganic arsenic and prevalence of diabetes mellitus," The American Journal of Epidemiology, vol. 139, no. 5, pp. 484-492, 1994.
[68] F. S. Walton, A. W. Harmon, D. S. Paul, Z. Drobná, Y. M. Patel, and M. Styblo, "Inhibition of insulin-dependent glucose uptake by trivalent arsenicals: possible mechanism of arsenic-induced diabetes," Toxicology and Applied Pharmacology, vol. 198, no. 3, pp. 424-433, 2004.

[69] Z. X. Wang, C. S. Jiang, L. Liu et al., "The role of Akt on Arsenic trioxide suppression of 3T3-L1 preadipocyte differentiation," Cell Research, vol. 15, no. 5, pp. 379-386, 2005.

[70] Y. Hou, P. Xue, C. G. Woods et al., "Association between arsenic suppression of adipogenesis and induction of CHOP10 via the endoplasmic reticulum stress response," Environmental Health Perspectives, vol. 121, no. 2, pp. 237-243, 2013.

[71] D. Bartoli, G. Battista, M. de Santis et al., "Cohort study of art glass workers in Tuscany, Italy: mortality from non-malignant diseases," Occupational Medicine, vol. 48, no. 7, pp. 441-445, 1998.

[72] P. E. Enterline and G. M. Marsh, "Cancer among workers exposed to arsenic and other substances in a copper smelter," The American Journal of Epidemiology, vol. 116, no. 6, pp. 895911, 1982.

[73] G. E. Jensen and M. L. Hansen, "Occupational arsenic exposure and glycosylated haemoglobin," Analyst, vol. 123, no. 1, pp. 7780, 1998.

[74] J. H. Lubin, L. M. Pottern, B. J. Stone, and J. F. Fraumeni Jr., "Respiratory cancer in a cohort of copper smelter workers: results from more than 50 years of follow-up," The American Journal of Epidemiology, vol. 151, no. 6, pp. 554-565, 2000.

[75] A. H. M. N. Nabi, M. M. Rahman, and L. N. Islam, "Evaluation of biochemical changes in chronic arsenic poisoning among Bangladeshi patients," International Journal of Environmental Research and Public Health, vol. 2, no. 3-4, pp. 385-393, 2005.

[76] M. Rahman, M. Tondel, I. A. Chowdhury, and O. Axelson, "Relations between exposure to arsenic, skin lesions, and glucosuria," Occupational and Environmental Medicine, vol. 56, no. 4, pp. 277-281, 1999.

[77] C. Steinmaus, Y. Yuan, J. Liaw, and A. H. Smith, "Low-level population exposure to inorganic arsenic in the United States and diabetes mellitus a reanalysis," Epidemiology, vol. 20, no. 6, pp. 807-815, 2009.

[78] K. Tollestrup, F. J. Frost, L. C. Harter, and G. P. McMillan, "Mortality among children residing near the American Smelting and Refining Company (ASARCO) copper smelter in Ruston, Washington," Archives of Environmental Health, vol. 58, no. 11, pp. 683-691, 2003.

[79] N. I. Ward and B. Pim, "Trace element concentrations in blood plasma from diabetic patients and normal individuals," Biological Trace Element Research, vol. 6, no. 6, pp. 469-487, 1984. 

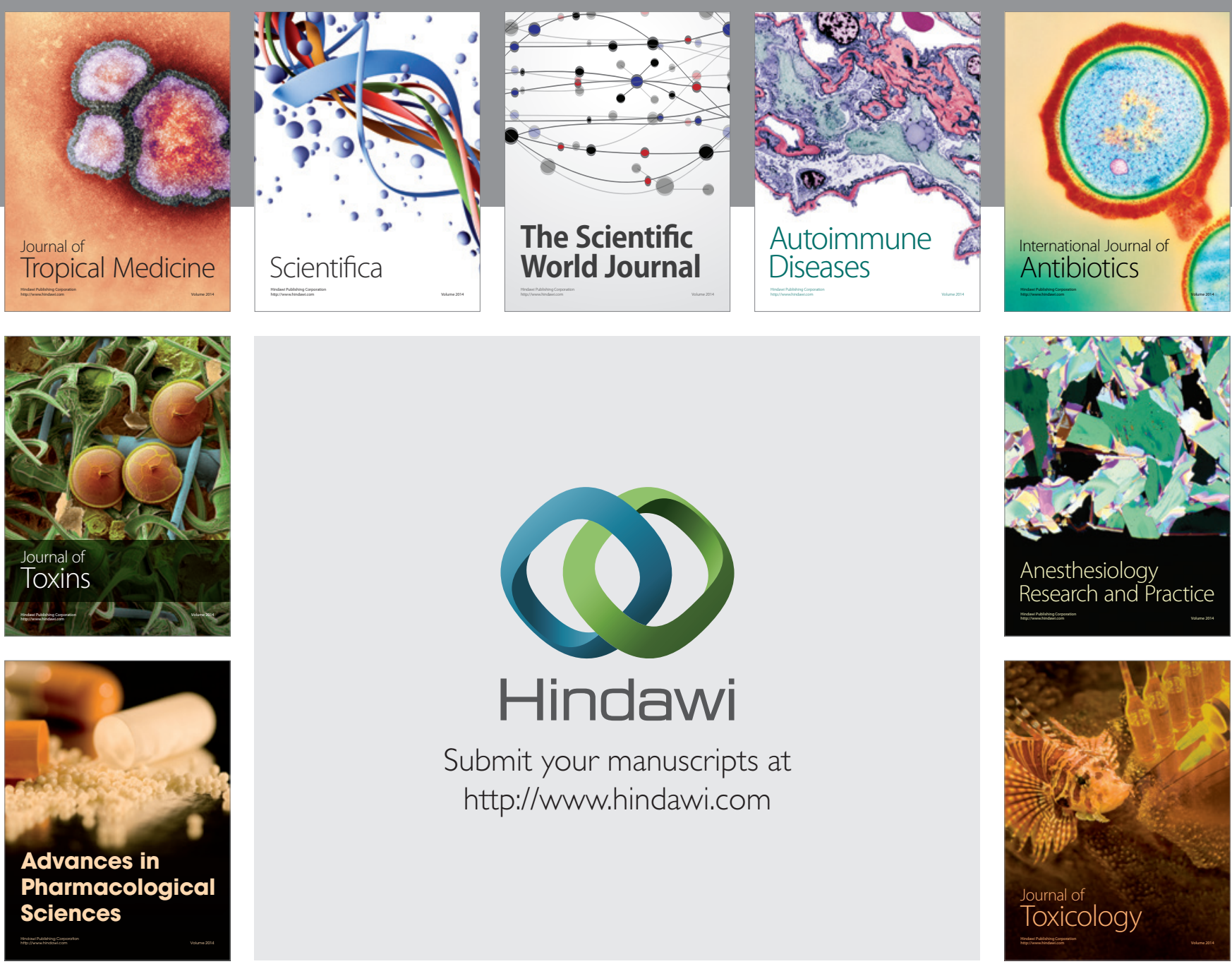

\section{Hindawi}

Submit your manuscripts at

http://www.hindawi.com
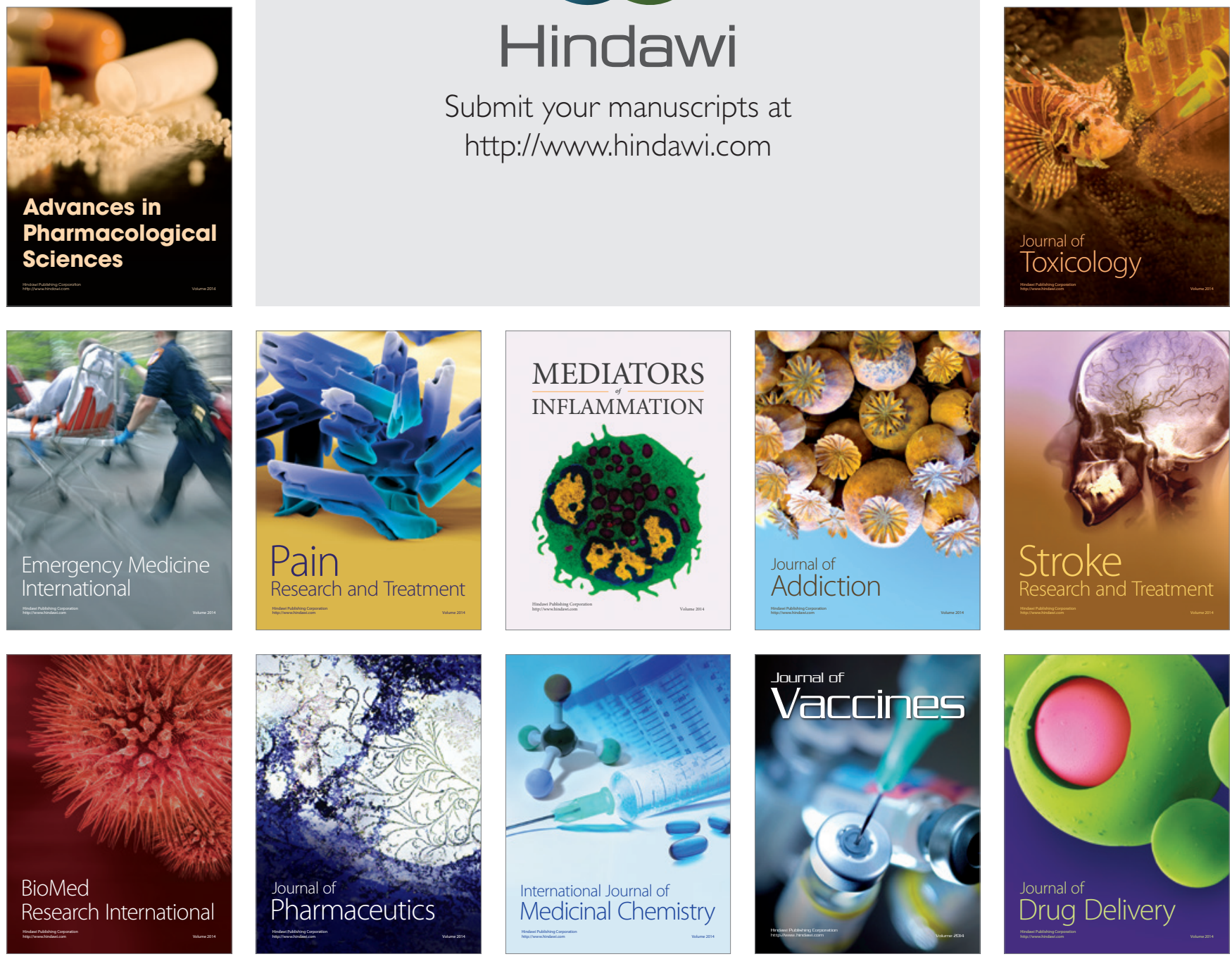